\title{
PERAN STRATEGI MANAJEMEN SUMBERDAYA MANUSIA DALAM MENCAPAI KEUNGGULAN BERSAING PADA ERA KOMPETISI GLOBAL
}

\author{
Oleh : \\ Agung Utama \\ agung_utama@uny.ac.id
}

\section{ABSTRACT}

Global competition indicated by the emerging of much competitors operate in the world market and the emerging of the competitors in other countries caused business environment becomes dynamic and tightly competition. Pursuing competitive advantage becomes the key factor on winning the competition on such environment through managing the activities of human resources based on strategic perspective. Based on this perspective, the strategy of human resource must relevance with the business strategy. Typology of human resource management strategy is an alternative approach for formulation that strategy. Identifing the needed role behavior of competitive strategy becoming the important factor on effectiveness of competitive strategy implementation.

Key words: Global Competition, Typology of Strategy Of HRM, Competitive Strategy

\section{Pendahuluan}

Tahun 1990 merupakan dekade awal dimana perusahaanperusahaan diseluruh dunia harus memulai berfikir global. Waktu dan jarak menjadi semakin tidak berarti dengan kemajuan teknologi, komunikasi, transportasi, dan arus keuangan. Produk-produk yang ditemukan dan dikembangkan disuatu negara seperti tas merk Gucci, hamburger dari Mc Donald's, pakaian pria dari Pierre Cardin, BMW dari Jerman, dan produkproduk lain mendapat tanggapan secara antusias di negara-negara lain. Tampaknya suatu pemukiman global sedang muncul. Fenomena ini mengingatkan kita tentang pemikiran Global Village yang pernah dicetuskan oleh Ohmae dan Drucker. Mereka menyatakan bahwa mekanisme perdagangan dunia saat ini digambarkan sebagai sebuah pasar disebuah desa. Artinya pasar semakin kecil (compressed) dengan dunia yang semakin terasa kecil karena dukungan kemajuan teknologi dan informasi yang tidak pernah terbayangkan sebelumnya. Teknologi dan informasi merupakan elemen penting bagi perusahaan dimasa yang akan datang sehingga 
memungkinkan pexusahaan untuk berinovasi, memberikan respon yang cepat terhadap konsumen (Chatell, 1995: 89).

Selama beberapa dekade ini banyak perusahaan telah melakukan aktifitas internasionalnya. Nestle, Toshiba, Shell, Bayer, dan masih banyak lagi perusahaan multi nasional yang sudah sangat dikenal oleh konsumen-konsumen diseluruh dunia. Perusahaan-perusahaan domestik yang sebelumnya tidak pernah berfikir akan perusahaan asing, sekarang ini menghadapi langsung pesaing-pesaing ini. Sudah tidak asing lagi bagi kita mendengar

keberhasilan perusahaan-perusahaan Jepang. dibandingkan perusahaan Amerika Serikat dalam memasarkan produkproduknya berupa alat-alat elektronik, mobil, kamera, jam tangan, dan produk-produk lainnya di pasaran Amerika Serikat. Fenomena tersebut menjelaskan betapa lingkungan bisnis telah berubah secara radikal dan sangat berbeda dengan masa lalu. Perubahan ini disebabkan oleh terjadinya hipercompetition dalam perekonomian global. Menurut D'aveni dan Gunther, Hipercompetition merupakan persaingan yang terjadi dalam lingkungan yang terus menerus mengalami perubahan secara cepat dalam kurun waktu yang semakin singkat (D'aveni dan Gunther, 1995:
178) Kecepatan dan pendeknya periode perubahan lingkungan menyebabkan perusahaan tidak terlalu mudah untuk melakukan antisipasi dalam upaya menghindari kegagalan-kegagalan. Perusahaanperusahaan yang ingin bertahan dan lebih maju dalam kondisi demikian perlu untuk mengembangkan strategi yang baru. Dalam keadaan demikian perusahaan seharusnya memperlakukan dunia sebagai sumber penawaran dan permintaan. Mereka-mereka ini tidak terbatas pada perushaan internasional saja, tetapi juga perusahaan domestik baik besar maupun kecil. Fokus harus diarahkan pada penciptaan laba dan pertumbuhan didalam pasar global yang menunjukan arus produk, teknologi, modal, dan bisnis yang besar antar negara. Dalam kondisi perekonomian seperti ini tidak ada satupun pasar yang selamanya aman dari persaingan. Bagi perusahaan-perusahaan yang selama ini hanya beroperasi dipasar domestik lambat laun akan mengalami persaingan yang keras hingga didapatkan kenyataan bahwa pasar domestic itu tidak ada lagi, serta yang ada hanyalah pasar global.

\begin{tabular}{lrr}
\multicolumn{1}{c}{ Hal tersebut diatas } \\
dimaksudkan utnuk menunjukkan \\
bahwa bukannya r semua \\
perusahaan harus go international \\
tetapi harus membuat perencanaan \\
untuk pertumbuhan dan \\
kelangsungan hidup diera
\end{tabular}


persaingan global. Tentunya perusahaan tidak dapat mengandalkan untuk hidup dipasar domestik saja. Dengan kata lain tidak terdapat lagi tempat bagi perusahaan-perusahaan untuk bersembunyi dari pesaing-pesaing di luar negeri. Dalam kondisi demikian maka tidak ada pilihan lain bagi perusahaan yang berada dalam era persaingan global untuk tidak ikut berkompetisi global melalui peningkatan kemampuan bersaing secara global. Salah satu faktor kunci dalam menentukan keberhasilan persaingan tersebut adalah melalui upaya pencapaian keunggulan kompetitif (bersaing) perusahaan atau organisasi. Alternatif pendekatan yang mungkin diterapkan oleh perusahaan atau organisasi pada kondisi seperti ini adalah melalui pengelolaan aktifitas-aktifitas sumber daya manusia dalam perusahaan atau organisasi berdasarkan pada perspektif strategik. Pada prinsipnya perspektif ini menjelaskan bahwa dalam upaya mencapai keunggulan bersaing (kompetitif) maka strategi sumber daya manusia harus sesuai dengan strategi bisnis perusahaan. Tulisan ini dimaksudkan untuk menjelaskan bagaimana mengelola sumber daya manusia yang ada pada perusahaan atau organisasi guna mencapai keunggulan kompetitif pada era kompetisi global dari perspektif stategi manajemen sumber daya manusia.
PEREKONOMIAN GLOBAL

Kondisi perekonomian dewasa ini sudah menunjukkan kecenderungan yang bersifat global. Hubungan antar negara atau bangsa-bangsa di dunia dibidang ekonomi mulai tidak mengenal batas- batas wilayah negara secara geografis. Kenichi Ohmae (1995: 128), menyebut masa - sekarang sebagai masa berakhirnya negara bangsa dan masa munculnya negara wilayah. Negara wilayah terbentuk dari beberapa negara bangsa di suatu wilayah yang membuat kesepakatan untuk melakukan perdagangan bebas. Sebagai contoh adalah wilayah yang mencakup negara-negara Eropa Barat, ASEAN, dan Amerika Utara.

Menurut Daniels dan Daniels, istilah globalisasi dapat diartikan sebagai pengkondisian yang mencakup( Daniels dan Daniels, 1993: 69):

- Pelaksanaan bisnis disejumlah negara di dunia.

- Penyeimbangan kualitas global barang dan jasa serta kebutuhan unik dari berbagai basis pelanggan local.

- Penggolongan kualitas etnosentrik yang secara cultural tidak menunjukkan batas yang jelas, apapun kebangsaannya.

- Pemanfaatan sumber dan keahlian tanpa memandang jenis kewarganegaraannya. 
Dengan mengacu pada pengertian diatas dapat dipahami bahwa dalam perekonomian global, dimanapun keberadaan konsumen di dunia ini karakteristik kebutuhan dan keinginannya cenderung tidak berbeda. Perekonomian global baru sedang terjadi yang menghadapkan perusahaan-perusahaan dengan berbagai ancaman terhadap kelangsungan hidup mereka disamping peluang-peluang untuk mencapai pertumbuhan dan laba. Ohmae memandang bahwa negara bangsa telah kehilangan kemampuan untuk mengendalikan tingkat pertukaran dan proteksi mata uangnya disamping juga tidak dapat membangkitkan aktifitas ekonominya (Ohmae, 1985: 55). Oleh karena itu keterlibatan sebagai peserta dalam perekonomian global harus diperkuat hubungan aktifitas antar bangsa yang semakin dekat.

\section{Kekuatan-Kekuatan Yang Membentuk Perekonomian Global Perekonomian global} terbentuk oleh adanya dorongan berbagai kekuatan yang mencakup beberapa hal sebagai berikut (Dharmesta, 1997: 27):

- Perubahan teknologi yang tercermin pada migrasi industri dari negara maju ke negara sedang berkembang.

- Realokasi dari industri-industri yang padat karya dan modal tradisional ke industri yang padat teknnologi dan keahlian
- Tingkat inflasi yang semakin tinggi, menyangkut kecepatan, ketersediaan, dan efektifitas biaya komunikasi internasional.

\section{Aktor Dalam Perekonomian Global}

Terciptanya perekonomian global sudah ditunjukan oleh adanya kecenderungan sejak tahun 1980-an. Ohmae, telah mengidentifikasi adanya tiga poros kekuatan ekonomi dunia, disebut Triad Power, yang mendominasi perekonomian dunia (Ohmae, 1985:19). Berbagai kaukus ekonomi multilateral yang dibentuk oleh berbagai negara dikawasan tertentu ikut berpengaruh terhadap terciptanya perekonomian global (Dharmesta, 1997:31).

\section{- Tiga poros kekuatan ekonomi}

Tiga poros ekonomi ini meliputi Amerika Serikat, Jepang, dan masyarakat Eropa. Kombinasi produk domestic bruto dari ketiga porors tersebut membentuk dua per tiga PDB dunia, yaitu Amerika Serikat $26 \%$, masyarakat Eropa $25 \%$ dan Jepang 14\%. Ekspor impor mereka menguasai empat per lima dari ekspor impor dunia. Volume perdagangan antara ketiga poros itu sebesar dua per tiga dari perdagangan dunia. Sedangkan investasi langsung 
asingnya (FDI) mencapai tiga per empat dari arus keluar FDI dunia dan dua per tiga dari arus masuk FDI dunia per tahunnya. Meskipun dominasinya terus menurun namun ketiga poros tersebut masih menjadi pusat perekonomian global di abad 21.

- Masyarakat Eropa

Sejak terbentuknya masyarakat Eropa tahun 1960an, telah ditetapkan tujuan yang jelas yaitu penciptaan pasar umum (common market) termasuk menghilangkan hambatan-hambatan dalam perpindahan barang, jasa, orang dan modal diantara sesama anggota. Ide penyatuan menjadi pasar tunggal muncul sebelum tahun 1980. Perusahaan-perusahaan dinegara anggota menganggap pentingnya pasar tunggal Eropa sebagai basis kekuatan ekonominya menghadapi pesaing Amerika Serikat dan Jepang. Oleh karena itu semua hambatan dalam perdagangan, investasi, dan perusahaan dihapuskan pada tahun 1992, bahkan negara-negara itu sepakat untuk menyatukan mata uang mereka pada tahun 1998. Dengan demikian perusahaanperusahaan dapat menekan biaya secara penuh keunggulan

kompetitif nasional, skala ekonomi dan efek pembelajaran. Tingkat persaingan yang semakin ketat akan menguntungkan konsumen dalam bentuk harga yang rendah, kualitas yang tinggi dan lebih banyak pilihan.

- Kelompok NAFTA

NAFTA atau North Emerican Free Trade Agreement terbentuk tahun 1992 dengan anggota sebanyak tiga negara, yaitu AS, Kanada, dan Mexico. Mereka telah menyepakati dihapuskannya hambatanhambtan dalam perdagangan dan investasi. Dengan PDB 6 trilun As dolar dan jumlah konsumen 360 juta, area pasar bebas amerika utara itu dapat menyaingi masyarakat eropa sebagai pasar tunggal terbesar.

- Jepang

Jepang merupakan pasar yang sulit dimasuki. Akan tetapi akhir- akhir ini pasar mereka sudah semakin terbuka, khususnya bagi produk Eropa dan Amerika. Dengan produk yang tepat dan strategi pemasaran yang tepat, para pengusaha Eropa dan Amerika dapat bersaing dipasar Jepang dan bahkan dapat berkembang seperti yang telah dicapai oleh Apple Computers, Xerox, 
Johnson, dan masih banyak produk yang lain.

- Eropa Timur dan China.

Pola ekonomi terpimpin atau perencanaan terpüsat telah diterapkan dinegara-negara Eropa Timur dan China selama beberapa decade tanpa memperhatikan kekuatan pasar maupun transaksi bebas dengan ekonomi negara lain. Namun, saat ini mereka telah berubah. Negara-negara dengan seperempat penduduk dunia ini telah beralih ke sistem berbasis pasar yang memungkinkan untuk berpartisipasi secara penuh dalam perekonomian global seingga pengaruhnya pasti akan nampak.

- Negara-negara Industri baru

- Negara-negara industri baru yang dikenal dengan nama Newly Industriliazing Countries ( NIC), terdiri atas Korea Selatan, Hongkong, Taiwan, dan Singapura. Perekonomian mereka yang mènjadi sangat maju menjadi penentang dominator karena dapat mengurangi kesenjangan teknologi, lebih mudah mendapatkan akses terhadap modal internasional, biaya murah serta tenaga kerja yang produktif. Mereka menjadi pesaing berat bagi ME, AS, dan Jepang. NIC tersebut percaya bahwa penciptaan pasar bebas dapat berdampak pada kemajuan ekonomi.

- APEC

Asia Pacific Economic Cooperations (APEC) yang beranggotakan negara-negara dikawasan Asia Timur dan Pasifik, termasuk Jepang dan As yang sudah kuat telah diperkirakan akan menjadi pasar bebas yang sangat besar dan memacu pengembangan pasar global. Mereka telah bersepakat membuka pasar bebas pada tahun 2020.

\section{- AFTA}

Asean Free Trade Agreement (AFTA), mencakup negaranegara Asean, yaitu Brunei, Indonesia, Malaysia, Singapura, dan Thailand. Tahun 2003 telah menjadi patokan mereka untuk melakukan liberalisasi perdagangan dan investasi. Upaya ini sejalan dengan upaya APEC yang keanggotannya mencakup mereka juga.

Lingkungan, Strategi Bisnis dan Strategi Manajemen SDM

Faktor-faktor lingkungan seperti halnya ketidakpastian, inovasi teknologi, perubahan demografis, organisasi yang 
menjadi lebih flat dan fleksibel, meningkatnya kolaborasi dan kompetisi multinasional berpengaruh terhadap strategi sumberdaya manusia. Hasil penelitian Fombroun (1982) menyatakan bahwa perubahan dalam pemrosesan iniormasi, automasi, inflasi, produksi, demografis, elitis, serta politik keperitingan kelompok berpengaruh terhadap struktur organisasi dan isu-isu sumberdaya inanusia (Fombroun, 1982, 65). Fombroun menyatakan bahwa perubahan teknologi sangat berpengaruh terhadap pekerjaan-pekerjaan di bidang jasa, perubahan di bidang ekonomi sanyat berpengaruh terhadap alternative kompensasi dan pelatihan karyawan serta perubahan sosial berpengaruh terhadap perubahan pengembangan organisasi, promosi dan sistem penilaian formal organisasi. Sebagai konsekuensi dari perubahan berbagai faktorfaktor lingkungan seperti halnya inovasi teknologi, perubahan demografis, serta situasi ketidakpastian lingkungan bisnis maka strategi bisnis dan sekaligus strategi sumberdaya manusianya akan mengalami perubahan. Smith, menyatakan bahwa pendekatan yang bisa digunakan dalam menyesuaikan strategi sumberdaya manusia dengan strategi bisnis atau kondisi organisasi adalah melalui penciptaan kesesuaian antara kebijakan sumberdaya manusia dengan pilihan strategi yang spesifik. Smith menyatakan bahwa meskipun rencana pemasaran, keuangan, dan teknik seringkali berubah untuk mencerminkan perubahan strategi, tetapi fungsi sumberdaya manusia seringkali diabaikan ( Smith, dalam Cynthia dan Mark Lengnickhall,1990:459). Dengar demikian perlu adanya kesesuaiar: antara strategi bisnis dengan strategi sumberdaya manusia dikarenakan kesesuaian kedua strategi ini akan merióukung keberhasilan implementasi strategi dan pencapaian keunggulan bersaing (kompetitif) perusahaar atau organisasi. Menurut Cynthia dan Mark Lengnickhall, Typology strategi sumberdaya manusia merupakan salahsatu pendekatan yang digunakan dalam merumuskan strategi sumberdaya manusia yang sesuai dengan stiategi bisnis (Cynthia dian Mark Lengnickhall,1990:461). Typology tersebut dinyatakan dalam bentuk matriks "Growth/Readiness". Dalam matriks tersebut, sumbu tegaknya adalah corporate growtí expectations, dimana growtli yang tinggi menunjukkan tingginya peluang, berbagai opsi strategi yang tersedia, cash flow yang tinggi serta ekspansi. Sumbu datarnya menyatakan

organizational readiness yang menunjukkan ketersediaan atau pencapaian, skill, gaya, dan pengalaman sumberdaya manusia yang diperlukan bagi implementasi strategi. Readiness 
merupakan proksi bagi kelayakan implementasi dan "menunjukkan seberapa baik sumberdaya manusia fit dengan kebutuhan pada situasi tersebut. Keempai kuadran pada matriks tersebut menunjukkan empat kondisi dimaña strategi sumberdaya diformulasikan akan diformulasikan agar sesuai dengan strategi bisnis perusahaan atau organisasi dalam mencapai keunggulan bersaing (kompetitif). Matriks tersebut digambarkan sebagai terikut:

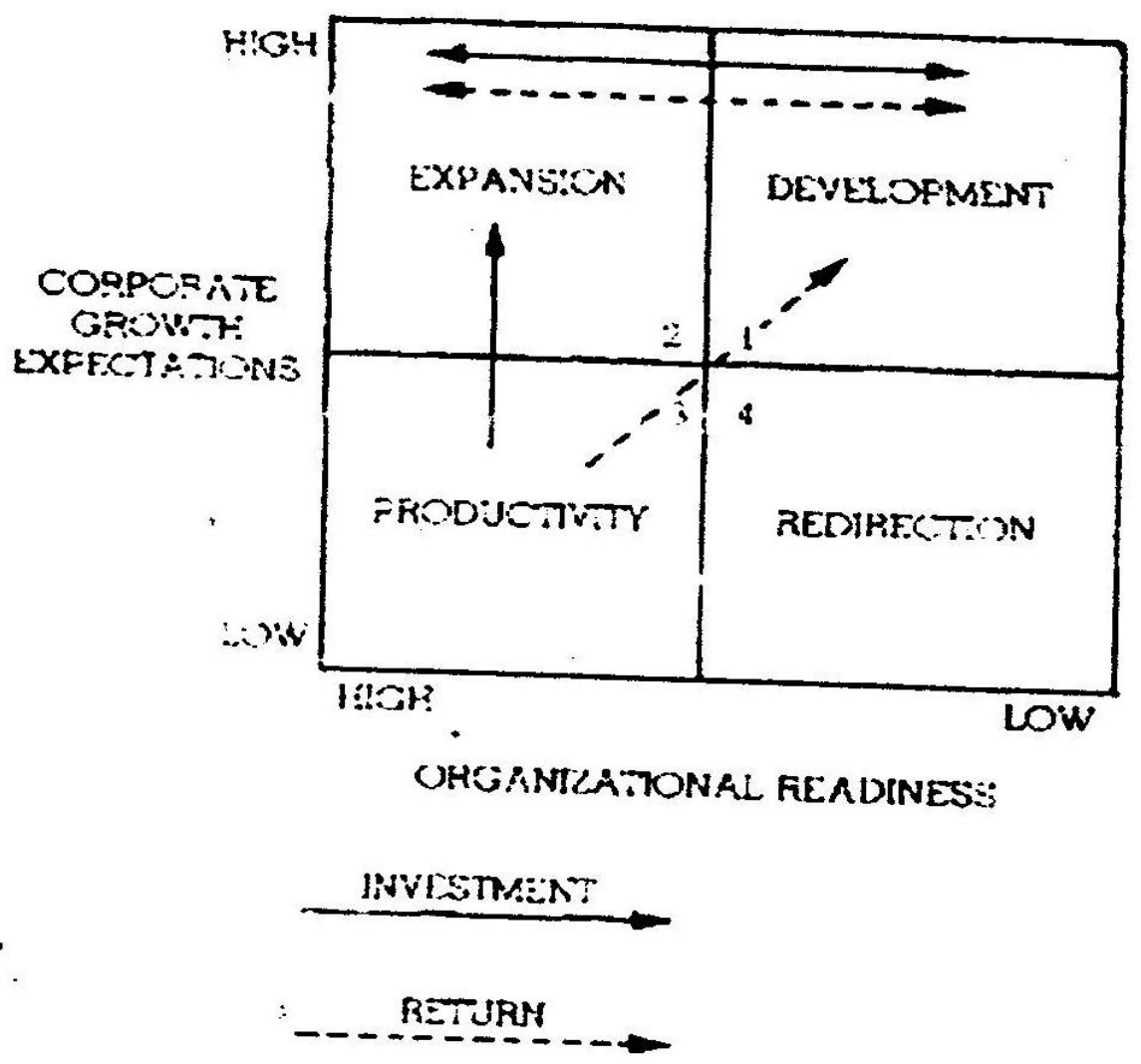

Gambari: Growth/Readiness Matrix

Sumber: (Cynthia dan Mark Lengnickhall,1990:461)

Keempat kuadran beserta alternative strateginya dijabarkan sebagai berikut:

\section{Kuadran satu : Development}

Kuadran ini dicirikan oleh ekspektasi growth yang tinggi dan tingkat readiness yang buruk antara strategi dengan skill sumber daya manusia. Pada kuadran ini terdapat tiga alternatif strategi sumber daya manusia yaitu :

- Perusahaan melakukan investasi yang tinggi pada bidang sumber daya manusia seperti halnya investasi yang dilakukan oieh Hyatt untuk melakukan 
pelatihan kembali terhadap karyawan Braniff setelah perusahaan tersebut diakusisi.

- Merubah tujuan corporat yang mencerminkan kurangnya readiness, seperti yang dilakukan oleh Sambo yang merubah focus dari pertumbuhan ke profit setelah mengalami kesulitan keuangan pada tahun 1983.

- Merubah strategi corporat untuk mempergunakan ketrampilan dan sumber daya yang tersedia pada saat itu. Hal ini dilakukan oleh Anheuser-Busch yang mundur dari industri soft drink dan masuk ke industri snack dan bakery.

\section{Kuadran Dua : Exspansion}

Kuadran ini dicirikan oleh ekspektasi growth yang tinggi dan readiness yang baik antara strategi dengan kinerja. Perusahaanperusahaan yang berada pada kuadran ini pada umumnya merupakan perusahaan yang memiliki posisi persaingan dalam industri yang kuat. Permasalahan yang muncul pada pada kuaradran ini adalah masalah alokasi sumberdaya perusahaan yakni seberapa besar proporsi sumberdaya yang akan dialokasikan untuk mencapai pertumbuhan yang diinginkan, serta seberapa besar proporsi sumberdaya yang dibutuhkan untuk mengelola pertumbuhan. Solusi atas permasalahan tersebut sangat tergantung dari:1). Tingkat investasi pada sumberdaya manusia yang diperlukan untuk mempertahankan yang

2).Profitabilitas,3).Ukuran kinerja lain yang penting bagi perusahaan. Perumusan alternatif strategi manajemen sumberdaya manúsía untuk mengatasi masalah alokasi sumberdaya ini

perlu mempertimbangkan hal- hal berikut: 1). Identifikasi terhadap trend yang relevan dengan produk, organisasi dan siklus hidup industri, 2). Identifikasi terhadap biaya tidak langsung dalam mencapai pertumbuhan, 3). Identifikasi terhadap biaya dalam mengelola pertumbuhan, 4). Biaya pencapaian dan mempertahankan pertumbuhan perlu dibandingkan dengan pendapatan yang akan dihasilkan dari peningkatan pertumbutian.

\section{Kuadran Tiga : Productivity}

Kuadran ini dicirikan oleh ekspektasi growth yang rendah serta readiness yang baik bagi implementasi strategi. Sebagai contohnya adalah perusahaan Mercedes Benz ataupun Kroger Stores. Dikarenakan perusahaan ini memiliki keunggulan kompetitif serta tidak melakukan ekspansi secara cepat maka operasi perusahaan ini bisa berjalan secara efektif dan efisien. 
Pada kuadran ini terdapat beberapa alternatif strategi sumber daya manusia yaitu :

- Perusahaan berfokus pada persiapan terhadap perubahan-perubähan yang sudah diantisipasi yang akan terjadi pada bisnis utama. American Exspress memilih strategi ini dalam rangka menghadapi deregulasi, dimana sumber dayanya diinvestasikan pada bisnis yang terkait atau tidak dengan portofolio.

- Perusahaan berfokus pada upaya memperbaiki posisi persaingan saat ini. Fokus ini mencakup penggunaan sumber daya dalam rangka memperbaiki mentoring, pengembangan rencána suksesi, dan sebagainya dalam upaya membenahi kelemahan organisasi.

\section{Kuadran Empat : Redirection}

Kuadran ini dicirikan oleh ekspektasi growth dan readiness yang buruk. Perusahaanperusahaan yang berada pada kuadran ini pada umumnya merupakan perusahaan yang berada pada industri yang sedang mengalami penurunan, produkproduknya yang telah usang ataupun proses manufacturing yang tidak lagi kompetitif (Porter, dalam Cynthia dan Mark Lengnickhall, 1990:465). kuadran ini pilihan strateginya adalah : perusahaan harus merubah haluan (turnaround) ataukah keluar (exit) dari bisnis. Pada kuadran ini perusahaan harus memutuskan apakah perusahaan akan mengalihkan aktifitas-aktifitas karyawannya ataukah merubah fokus bisnis, dalam hal ini sumber daya manusia maupun pertimbangan kompetitif merupakan hal yang paling penting. Jika merubah haluan merupakan alternatif strategi yang dipilih, maka diperlukan upaya-upaya pelatihan kembali, penyesuaian kembali serta restrukturisasi pada perusahaan atau organisasi tersebut. Tetapi bila perusahaan memilih untuk keluar dari bisnis, maka dihadapkan pada kewajiban tentang perpindahan karyawan dan relokasi perusahaan. Pada kuadran ini perlu diperhatikan tiga hal dalam implementasi strategi sumber daya manusia yaitu evaluasi kondisi industri, penilaian posisi persaingan serta analisis kelayakan dalam mendukung kesuksesan implementasinya

\section{Strategi Bersaing: Perilaku Peran Yang Dibutuhkan}

$$
\text { Keunggulan }
$$

bersaing (kompetitif) merupakan satu kunci sukses bagi perusahaan atau organisasi yang berada dalam lingkungan yang terus menerus mengalami perubahan secara cepat dalam kurun waktu yang semakin singkat atau berada dalam lingkungan persaingan yang ketat. 
Pada prinsipnya, konsep keunggulan bersaing yang dikemukakan oleh Porter merupakan esensi dari strategi bersaing (competitive sirategy). Menurut Porter, terdapat tiga strategi bersaing bagi perusahaan atau organisasi yang bertujuan menciptakan keunggulan bersaing atau competitive strategy (Porter, 1995: 149). Ketiga strateg! tersebut adalah : strategi inovasi (the innuvation strategy), strategi peningkatan kualitas produk/jasa (the quality enhancement strategy), dan strategi pengurangan biaya (cost reduction). Bagi peiusahaan atau organisasi agar mampu berhasil mengimplementasikan bersaing, maka kesesuaian antara strategi bersaingnya dengan karakteristik personel ataupun perilaku peran yang dibutuhkan. Hal ini korisisten dengan hasil penelitian yang dilakukar oleh Hay Grcup ir Corporated dan University of Michigan and The Strategic Planing Institute yang menyatakan bainwa perusahaan yang menerapkan strategi pertumbuhan memerlukan manager puncak yang bersedia melepaskan status quo serta menyesuaikan strategi dan tujuannya pada pasar (Schuler dan Jackson, 1987:207). Peran yang diperlukan bagi sumber daya manusia (karyawan) yang ada pada perusahaan atau organisasi pada hakekatnya merupakan apa yang diperlukan oleh perusahaan atau organisasi terhadap sumber daya manusia (karyawan) yang dimilikinya selain faktor kemampuan teknis, pengetahuan serta kemampuan yang diperlukan dalam mergerjakan pekerjaan spesifik atau merupakan apa yang dibutuhkan dari karyawan yang bekerja bersama dengan orang lain dalam lingkungan sosial. Schuler dan Jackson menyatakan bahwa diperlukan perilaku peran tertentu bagi sumberdaya manusia (karyawan) yang ada dalam perusahaan atau organisasi agar impiementasi strategi bersaing yang telah ditentukan dapat berjalan secara efektif. Perilaku peran yang dibutuhkan dalam impementasi tersebut dijabarkan sebagai berikut (Schuler dan Jackson, 1987:209):

e Strategi inovasi (the innovation strategy)

Strategi inovasi meiupakan strategi yang berusaha mengembarigkan produk dan jasa yang berbeda dari pesaingnya. Fokus utamanya terletak pada usaha menawarkan sesuatu yang baru dan berbeda (Porter, dalam Schuler dan Jakcson, 1987:208). Menurut Schuler dan Jakcson diperlukan beberapa perilaku peran sumber daya manusia yang ada pada perusahaan atau organisasi dalam mendukung implementasi strategi inovasi tersebut. Profil perilaku peran 
tersebut diantaranya adalah : 1). derajat perilaku kreatif yang tinggi, 2). Fokus jangka panjang, 3). Derajat perilaku interdependen dan kooperatif yang tinggi, 4j. Perhatian yang cukup terhadap kualitas, 5). Perhatian yàng cukup terhadap kuantitas, 6). Perhatian yang sama terhadap proses dan hasil, 7). Tidak takut resiko, 8). Toleransi yang tinggi terhadap ambiguity dan sesuatu yang bersifat unpredictable

Strategi

kualitas

qua!ity

strategy)

Merupakan strategi
yang berfokus pada upayaupaya perbaikan atau penyempurnaan kualitas produk atau jasa yang dihasilkan. Menurut Scholer dan Jakcson terdapat delapan profil tentang perilaku peran yang diperlukan dari sumber daya manusia (karyawan) dalam implementasi mendukung strategi peningkatan kualitas produk jasa. Prcfil tersebut diantaranya adalath : 1). perilaku yang bersifat repetitive dan predictable, 2). Fokus jangka parjang atau menengah, 3). Derajat perilaku interdependen cooperative yang moderat, 4). Perhatian yang tinggi terhadap kualitas, 5). Derajat perhatian yang moderat pada kuantitas,
6). Perhatian yang tinggi pada proses, 7), aktifitas yang tidak berisiko, 8).

Komitmen terhadap tujuan perusahaan.

Peningkatan kualitas produkJjasa seringkali merupakan perubahan sebuah proses produksi

yang mensyaratkan karyawan menjadi lebih fleksible dan terlibat dalam proses produksi. Ketika pekerjaan berubah, maka berubah pulalah sistem klasifikasi pekerjaan yang ada. Hak ini terjadi pada Brunwicks Mercliry Mlarine Division yang memangkas pekerjaannya dari 126 menjadi 12 sehingga menyebabkan fleksibilitas dalam proses produksi dan penggunaan

Karyawan kesempatan mempelajari karyawan. mendapatkan untuk ketiampilan yang baru yang pada akhirnya memiliki komitmen yang kuat pada organisasi serta bersedia untuk memberikan sesuatu yang lebih pada organisasi.

- Strategi Pengurangan Biaya. Strategi ini berusaha mendapatkan keunggulan bersaing melalui biaya produksi yang rendah. Perusahaan yang menerapkan strategi ini dicirikan oleh kontrol biaya yang ketat, minimisasi biaya 
overhead serta pencapaian skala ekonomis. Fokus utama diarahkan pada upaya meningkatkan produktivitas, yakni melalui biaya output per individu. Pada prinsipnya upaya pengurangan biaya ini dilakukan melalui pengurangan jumlah karyawan , penurunan tingkat upah karyawan, pemanfaatan karyawan paruh waktu, subkontrak, prosedur pengukuran dan penyederhanaan pekerjaan, perubahan aturan pekerjaan, serta fleksibilitas penugasan pekerjaan.

Menurut Schuler dan Jackson, terdapat beberapa profil perilaku sumberdaya manusia (karyawan) yang diperlukan dalam mendukung implementasi strategi pengurangan biaya. Profil tersebut adalah sebagai berikut: 1). Perilaku yang repetitive dan predictable, 2). Fokus jangka pendek, 3). Aktivitas individual atau otonomi, 4). Perhatian yang cukup terhadap kualitas, 5). Perhatian yang tinggi terhadap kuantitas, 6). Perhatian utama pada hasil, 7). Aktivitas yang beresiko rendah, 8). Drajat yang tinggi terhadap stabilitas.

Kesimpulan

masa $\begin{array}{r}\text { Persaingan global pada } \\ \text { sekarang ini telah }\end{array}$ menciptakan peluang dan tantangan bagi perusahaan atau organisasi yang ingin berperan dengan posisi kuat. Arus persaingan global telah menjadikan lingkungan bisnis berubah secara radikal dalam waktu yang relatif singkat serta persaingan antar perusahaan semakin ketat. Salah satu faktor kunci untuk menentukan keberhasilan dalam persaingan tersebut adalah pencapaian keunggulan bersaing perusahaan atau organisasi. Alternatif pendekatan yang mungkin diterapkan oleh perusahaan pada kondisi tersebut adalah melalui pengelolaan aktifitas-aktifitas sumberdaya manusia pada perusahaan berdasarkan perspektif strategik. Pada prisipnya, perspektif ini menjelaskan bahwa dalam upaya mencapai keunggulan kompetitif, maka strategi manajemen sumberdaya manusia yang ditentukan harus sesuai dengan strategi bisnis perusahaan atau organisasi. Tipologi strategi manajemen sumberdaya manusia merupakan pendekatan yang digunakan dalam merumuskan strategi manajemen sumberdaya manusia yang sesuai dengan strategi bisnis perusahaan atau organisasi. Tipologi ini digambarkan dalam bentuk matriks yang terdiri dari empat kuadran, yaitu: development, expansion, productivity, dan redirection. Dalam mendukung keberhasilan dan efektifitas strategi bersaing yarig 
sudah ditentukan, maka perlu diperhatikan perilaku peran yang dibutuhkan dalam mendukung implementasi alternatif strategi bersaing yang telah ditentukan karena setiap alternatif strategi tersebut membutuhkan " perilaku peran yang berbeda dalam implementasinya.

\section{Referensi}

Chattell, A. (1995), "Managing for the future", London, Mac Millan Press. Ltd

Cynthia A. Lengnick-Hall and Mark L. Lengnick-hall, "Strategic Human

ResourcesManagement: A Review of The Literature and a Proposed Typology", Academy Of management Review: 454-470.

D'Aveni, R.A. and R. Gunther (1995) "Hyper Competition : Managing The Dynamics of Strategic Maneuvering", New York : TheFree Press

Daniels, J.L. and N.C. Daniels (1993), "Global Vision : Building New Models for The Corporation of the Future", New York: Mc Graw Hill, Inc.
Basu Swastha DH, (1997),
"Meningkatkan Daya Saing
Perusahaan Dalam Era
Persaingan Global", Kajian

Bisnis : STIE Widya Wiwaha Yogyakarta.

Fombround,

C

"Environmental Trend Create

New Presures on Human Resources", Journal of Bisnis Strategy, I (3) 61-69.

Ohmae, K. (1985), "Triad Power", New York: The Free Press

Ohmae, K. (1995), " The End Of The Nation State: The Rise Of The Regional Economies", New York: The Free Press

Porter, M.E (1995), " Competitive Advantage: Creating And Sustaining Superior Performance", New York: Simon and Schuster.Inc

Randall S. Schuler And Susan E. Jackson (1987), "Linking Competitive Strategies with Human Resources management Practises", Academy of Management Execxutive, I (3) 207-219.

\section{Biodata}

Agung Utama, SE, MS.i

Tenaga Pengajar Jurusan Manajemen Fakultas IImu Sosial Dan Ekonomi Universitas Negeri Yogyakarta 